\title{
Фотоника среднего УФ-диапазона на основе AIGaN наногетероструктур
}

\author{
С.В. Иванов, В.Н. Жмерик \\ ФТИ им. А.Ф. Иоффе, Санкт-Петербург, 194021, ул. Политехническая, 26 \\ тел:+7 (812) 292-79-99, факс:+7 (812) 297-10-17, эл. почта: ivan@ beam.ioffe.ru
}

DOI 10.34077/RCSP2019-16

Доклад посвящен активно развивающейся фотонике среднего ультрафиолетового (УФ) диапазона длин волн $(\lambda=210-300 н м)$, использующей в качестве базовых материалов нитридные соединения $\mathrm{Al}_{\mathrm{x}} \mathrm{Ga}_{1-\mathrm{x}} \mathrm{N}(x=0-1)$ с шириной запрещенной зоны от 3.4 до 6.1 эВ. УФ-фотодетекторы этого диапазона необходимы для развития солнечно-слепой фотосенсорики $(\lambda<290 \mathrm{HM})$, а источники спонтанного и лазерного УФ-излучения, найдут широкое применение в приборах оптической дезинфекции воды/воздуха/поверхностей $\quad(\lambda=230-260 н м), \quad$ в фототехнологиях, медицине, оптической спектроскопии, системах непрямой скрытой помехозащищенной связи $u \quad \partial p$. Плазменноактивированная МПЭ (ПА МПЭ) дает уникальные возможности эпитаксиального ступенчатослоевого роста гетероструктур (Al, Ga)N в металл-обогащенных условиях при относительно низких температурах (до $\sim 700^{\circ} \mathrm{C}$ ), что ограничивает развитие сегрегационных и диффузионных процессов в гетероструктурах. В сочетании со сверхбыстрым управлением ростовыми потоками $(<0.5 \mathrm{c})$ это позволяет формировать резкие интерфейсы между слоями, в том числе и монослойной толщины. Кроме того, ПА МПЭ позволяет выращивать в безводородной атмосфере слои $\mathrm{Al}_{\mathrm{x}} \mathrm{Ga}_{1-\mathrm{x}} \mathrm{N}$ с прецизионно контролируемым изменением состава, которые при их легировании $\mathrm{Si}(\mathrm{Mg})$ демонстрируют $n$-( $p$-)тип проводимости, усиленный поляризационными эффектами.

В докладе будут рассмотрены все основные стадии изготовления приборных гетероструктур на стандартных подложках $c$-сапфира с использованием нуклеационных и буферных слоев AlN, оптимизация роста которых позволила достичь практически нулевых средних упругих напряжений в 2-мкм буферных слоях и снизить в них плотности винтовых и краевых прорастающих дислокаций до $\sim 4 \cdot 10^{8}$ и $\sim 3 \cdot 10^{9} \mathrm{~cm}^{-2}$, соответственно. Затем будут обсуждены оптимальные режимы импульсных методов роста, включающих эпитаксию с повышенной миграцией адатомов, металл- и температурномодулированные эпитаксии, которые позволили получить атомарно-гладкие барьерные слои AlN и $\mathrm{Al}_{\mathrm{x}} \mathrm{Ga}_{1-\mathrm{x}} \mathrm{N}$ с однородным составом и контролируемой поверхностной концентрацией атомов III группы [1]. Основное внимание будет посвящено методам формирования и свойствам одиночных и множественных квантовых ям (КЯ) на основе монослойных и субмонослойных вставок GaN в барьерные слои $\mathrm{Al}_{\mathrm{y}} \mathrm{Ga}_{1-\mathrm{y}} \mathrm{N}$ или $\mathrm{AlN}$. Будут представлены результаты исследований таких КЯ с номинальной толщиной $d_{\mathrm{QW}}=0.5-7$ монослоев $(\mathrm{MC})$ с помощью атомарно-силовой и сканирующей просвечивающей электронной микроскопии, а также рентгенодифракционного анализа. Будет рассмотрено и объяснено необычное поведение упругих напряжений во время роста множественных KЯ GaN/AlN c $d_{\mathrm{QW}}<2 \mathrm{MC}$, при котором среднее напряжение в гетероструктуре остается нулевым несмотря на неизменную латеральную постоянную решетки AlN. Будут представлены результаты исследований оптических свойств слоев и гетероструктур с КЯ с помощью измерений спектров фото, электро- и катодолюминесценции. Будет продемонстрирована не только их оптическая активность в диапазоне среднего УФ излучения 235-300 нм при оптической, инжекционной и электронной накачках, но и резкое увеличение эффективности излучательной рекомбинации в суб-250 нм УФ диапазоне при уменьшении толщины КЯ в GaN/AIN гетероструктурах до $d_{\mathrm{Qw}}=1.5 \mathrm{MC}$ [2]. Структуры с такими множественными КЯ (до 360) продемонстрировали при электронной накачке спонтанное излучение с $\lambda=235-240$ нм и импульсной выходной мощностью до $\sim 1$ Вт. Кроме того, будут представлены результаты возбуждения в различных слоях и наногетероструктурах стимулированного излучения в диапазоне $\lambda=258-300$ нм с минимальной пороговой плотностью оптической мощности $\sim 150 \mathrm{kBT} / \mathrm{cm}^{2}(\lambda=290 \mathrm{Hм})$. И, наконец, будут представлены различные типы солнечно-слепых УФфотодетекторов на основе $p$-i-n фотодиодов, диодов Шоттки и фотокатодов с отрицательным электронным сродством, продемонстрировавших фоточувствительность до $34 \mathrm{MA} / \mathrm{cm}^{2}$ в диапазоне $\lambda=226-280 \mathrm{HM}$.

Работа осуществляется при частичной поддержке РФФИ-БРИКС (\#17-52-80089) и РНФ (\#19-7230040).

\section{Лumepamypa}

[1] Jmerik V.N., Nechaev D.V., Ivanov S.V. Molecular Beam Epitaxy (MBE): From Research to Mass

Production, 2nd Edition, ed. by M.Henini, Elsevier, 2018.

[2] Jmerik V.N. et al. Appl. Phys. Express 11, 091003 (2018). 